\title{
Carotenoids in the pulp and peel of bananas from 15 cultivars in two ripening $\operatorname{stages}^{1}$
}

\author{
César Fernandes Aquino ${ }^{2 *}$, Luiz Carlos Chamhum Salomão ${ }^{3}$,Helena Maria Pinheiro-Sant'ana ${ }^{4}$, \\ Sônia Machado Rocha Ribeiro ${ }^{4}$, Dalmo Lopes De Siqueira ${ }^{3}$, Paulo Roberto Cecon ${ }^{5}$
}

10.1590/0034-737X201865030001

\begin{abstract}
The current study aims to evaluate the occurrence and concentration of carotenoids in the pulp and peel of 14 banana and one plantain cultivars in two ripening stages. We analyzed the occurrence and content of lutein, $\alpha$ carotene, $\beta$-carotene, $\beta$-cryptoxanthin, and lycopene - by high performance liquid chromatography with UV-visible detection, the content of total carotenoids by spectrophotometry. In the unripe pulp, the 'Ouro' cultivar stood out with lutein concentration 13 times higher than that of the 'Marmelo'. As for á-carotene and $\beta$-carotene, 'Terrinha' plantain stood out with mean concentration of 1195.30 and $1126.11 \mu \mathrm{g}\left(100 \mathrm{~g} \mathrm{MF}^{-1}\right)$, respectively. Total carotenoids ranged from 159.66 to $2553.51 \mu \mathrm{g}\left(100 \mathrm{~g} \mathrm{MF}^{-1}\right)$ in 'Caipira' and 'Terrinha', respectively. In the ripe pulp there was $36 \%$ increase in the lutein content in comparison to the unripe pulp and there was 7.3 and $8.5 \%$ reduction in $\alpha$-carotene and $\beta$-carotene levels, respectively. The total carotenoid concentration in the ripe pulp was $17 \%$ higher than that found in the unripe pulp. The unripe peel showed lutein predominance, although 'Terrinha' stood out with higher $\alpha$-carotene and $\mu$ carotene concentrations than those found in the other cultivars. Lutein concentration hardly changed due to fruit ripening; however, there was slight reduction in $\alpha$-carotene and $\beta$-carotene concentrations.
\end{abstract}

Keywords: Musa spp.; provitamin A; lutein; $\alpha$-carotene; $\beta$-carotene.

\section{RESUMO}

\section{Carotenoides em polpas e cascas de bananas de 15 cultivares em dois estágios de maturação}

Este estudo objetivou caracterizar a dinâmica, além das mudanças estruturais e florísticas em uma comunidade arbAvaliou-se a ocorrência e aconcentração de carotenoides na polpa e na casca dos frutos de 14 cultivares de bananeira e um de plátano em dois estádios de maturação. Luteína, $\alpha$-caroteno, $\beta$-caroteno, $\beta$-criptoxantina e licopeno foram quantificados por cromatografia líquida de alta eficiência (CLAE), carotenoides totais por espectrofotometria. Na polpa verde, a banana 'Ouro' destacou-se com concentração de luteína 13 vezes maior que a da 'Marmelo'. Para $\alpha$-caroteno e $\beta$-caroteno, o plátano 'Terrinha' se destacou com concentração média de 1.195,30 e 1.126,11 $\mu \mathrm{g}$ (100 g $\left.\mathrm{MF}^{-1}\right)$, respectivamente. Os carotenoides totais oscilaram de 159,66 a 2.553,51 $\mu \mathrm{g}\left(100 \mathrm{~g} \mathrm{MF}^{-1}\right)$, para 'Caipira' e 'Terrinha', respectivamente. Na polpa madura, houve acréscimo de $36 \%$ no teor médio de luteína em relação à polpa verde e redução de 7,3 e 8,5\% nos teores médios de $\alpha$-caroteno e de $\beta$-caroteno, respectivamente. A concentração média de carotenoides totais na polpa madura foi $17 \%$ superior à da polpa verde. Na casca verde houve predominância da luteína, embora a 'Terrinha' tenha se destacado com concentrações de $\alpha$-caroteno e $\beta$-caroteno superior às dos demais cultivares. A concentração de luteína praticamente não se alterou com o amadurecimento dos frutos, no entanto houve discreta redução nas concentrações de $\alpha$-caroteno e $\beta$-caroteno.

Palavras-chave: Musa spp.; provitamina A; luteína; $\alpha$-caroteno; $\beta$-caroteno.

\footnotetext{
Submitted on August $6^{\text {th }}, 2017$ and accepted on June $25^{\text {th }}, 2018$.

${ }^{1}$ This work is part of the first author Doctoral thesis.

${ }^{2}$ Universidade Federal do Oeste da Bahia, Campus Barra, Barra, Bahia, Brazil. cesar.aquino@ufob.edu.br

${ }^{3}$ Universidade Federal de Viçosa, Departamento de Fitotecnia, Viçosa, Minas Gerais, Brazil. lsalomao@ufv.br; siqueira@ufv.br.

${ }^{4}$ Universidade Federal de Viçosa, Departamento de Nutrição, Viçosa, Minas Gerais, Brazil. helena.santana@ufv.br; sribeiro@ufv.br

${ }^{5}$ Universidade Federal de Viçosa, Departamento de Estatística, Viçosa, Minas Gerais, Brazil. cecon@ufv.br

*Corresponding author: cesar.aquino@ufob edu.br
} 


\section{INTRODUCTION}

Carotenoids are known for their wide distribution, structural diversity and multiple functions. Animals are unable to biosynthesize carotenoids. Thus, they depend on dietary provitamin A carotenoids, which can be absorbed and converted into vitamin A after ingestion (Rodriguez-Amaya \& Kimura, 2004). Besides being vitamin A precursors, some carotenoids present a number of health benefits such as the prevention of certain cancer types, the ability to prevent photosensitization in certain skin diseases, the increased immune response to certain infection types as well as anti-aging properties (Kurahashi et al., 2009).

The main carotenoids found in food are $\beta$-carotene, ácarotene, $\beta$-cryptoxanthin, lutein, lycopene and zeaxanthin (Rodriguez-Amaya \& Kimura, 2004). Among them, only $\beta$-carotene, $\alpha$-carotene and $\beta$-cryptoxanthin may convert into vitamin A in the body (Davey et al., 2009; Newilah et al., 2009). The presence of lutein, á-carotene and $\beta$-carotene has been reported in bananas (Wall, 2006; Davey et al., 2009; Newilah et al., 2009; Ekesa et al., 2012; Lokesh et al., 2014). Thus, two provitamin A carotenoids may be found in bananas, in addition to lutein, which is known as macular carotenoid (Davey et al., 2009).

Vitamin A deficiency is a major public health issue worldwide. It is more pronounced in developing countries and it mainly affects children, women in reproductive age and pregnant women (Davey et al., 2009; Ekesa et al., 2012). Thus, yellow and red fruits with high carotenoid concentration play a key role in preventing this deficiency, especially in regions where there is little food diversification or in those lacking provitamin-carotenoids-rich foods. One of the sustainable ways to mitigate the vitamin A deficiency issue is by encouraging the consumption of natural carotenoids-rich foods such as fruits and dark-greenleaf vegetables (Ekesa et al., 2012).

Banana production in Brazil is mainly concentrated in approximately six cultivars: 'Prata-Anã', 'Nanica', 'Nanicão', 'Pacovan' and to a lesser extent, 'Maçã' and 'Ouro'. However, there is huge diversity of cultivars known by the population, which are no longer cultivated, or which are cultivated in subsistence scale due to unfavorable agronomic features. Most of these cultivars, especially in Brazil, were not evaluated for the chemical composition of the fruits. Thus, it is imperative to evaluate the occurrence and to quantify the carotenoids concentrations found in a reasonable number of cultivars. In addition, studies evaluating the composition of banana cultivars in Brazil quantify total carotenoids alone (Amorim et al., 2009; 2011). Thus, it is not possible to express the vitamin A value.
Most studies evaluate just the ripe pulp and they do not provide information about the concentrations of different carotenoids in the unripe pulp, and in the unripe and ripe peels. It demonstrates the need for studies with bigger number of cultivars in different ripening stages, since concentrations may range depending on the cultivar, on the management conditions, on the cultivation regions and on the fruit ripening stage.

Thus, the current study aims to evaluate the occurrence and concentration of carotenoids in the pulp and peel of 14 banana and one plantain cultivars in two ripening stages.

\section{MATERIAL AND METHODS}

Bunches of Ouro (AA), Nanica (AAA), Nanicão (AAA), Caru-Verde (AAA), Caru-Roxa (AAA), Caipira (AAA), Prata (AAB), Prata-Anã (AAB), Maçã (AAB), Mysore (AAB), Pacovan (AAB), Marmelo (ABB), PrataGraúda (AAAB) and Caju (non-defined genomic group) banana and of Terrinha (AAB) plantain cultivars were harvested from $3.5 \mathrm{~m}$ x $2.5 \mathrm{~m}$ spaced plants in a six-yearold experimental orchard at Federal University of Viçosa (FUV), Viçosa, Minas Gerais, Brazil, located at $648 \mathrm{~m}$ altitude.

The bunches were harvested when the first signs of yellow peel were found in the fruits from each cultivar. The second, third and fourth hands were removed from each bunch and they were immediately transported to the Fruit Analysis Laboratory at the FUV campus. The fingers were cut off the hands and the damaged, sick and malformed fingers were discarded. Subsequently, they were washed with running water and left to rest on paper towels for a few minutes to coagulate the latex. Next, 12 fruits in color stage 1 (dark-green peel color) were randomly selected and six of them were immediately processed. The remaining six fruits were immersed in ethephon solution $\left(1.2 \mathrm{~g} \mathrm{~L}^{-1}\right)$ for $8 \mathrm{~min}$ to achieve uniform ripening. After they were air dried for $15 \mathrm{~min}$, they were dipped in Prochloraz fungicide solution $\left(0.49 \mathrm{~g} \mathrm{~L}^{-1}\right)$ for 5 minutes. After this time, the six fruits were placed in plastic boxes and kept at room temperature until they reached color stage 6 (fruits with completely yellow peel) which occurred within approximately 4 days.

The unripe and ripe pulp and peel samples were placed in aluminum wrap, weighted in semi-analytical balance, identified, subjected to freezing in liquid nitrogen, and placed in ultra-low temperature freezer at $-80^{\circ} \mathrm{C}$ until the time of the analysis, which occurred within approximately 180 days.

The $\alpha$-carotene, $\beta$-carotene, lutein, $\beta$-cryptoxanthin and lycopene occurrence and concentration in the unripe and ripe pulp and peel of 15 cultivars were evaluated. 
Carotenoids were extracted according to the method suggested by Rodriguez-Amaya (2001) with modifications. Five grams of plant material were weighed in appropriate extraction tubes, protected from direct light with aluminum foil, added with $60 \mathrm{~mL}$ cooled PA acetone (divided in three $20 \mathrm{~mL}$ volumes) and processed in UltraTurrax homogenizer (T18 basic model) for $6 \mathrm{~min}$. Then, the extract was vacuum filtered on Buchner funnel using filter paper. After filtration, the three extract fractions were transferred to separatory funnel containing $20 \mathrm{~mL}$ cold PA petroleum ether. Each fraction was washed with distilled water to completely remove acetone PA, anhydrous sodium sulfate was added to the extract in petroleum ether in order to remove any residual water from the extract. Subsequently, the extract in petroleum ether was transferred to a $25.0 \mathrm{~mL}$ volumetric flask, and the volume was completed with cold petroleum ether. The samples were not subjected to the saponification process.

Regarding the carotenoid analysis, $5.0 \mathrm{~mL}$ aliquots of the extract from each fruit part and ripening stage were evaporated under nitrogen gas flow, and the dry residue was recovered using $2.0 \mathrm{~mL}$ HPLC grade acetone. Then, the extracts were filtered in filtering units with 0.45 ì m (Millipore) porosity, and $100 \mu \mathrm{L}$ of them were injected into the chromatographic system to be analyzed.

Carotenoid analyses were performed by highperformance liquid chromatography with diode array detection (HPLC-DAD), according to the chromatographic conditions developed by Pinheiro-Sant'Ana et al. (1998). The equipment used in the analysis consisted of a Shimadzu gas chromatograph equipped with highpressure pump (LC-10ATVP model), automatic injector (SIL-10AF model) and diode array detector (SPD-M10A model), and it was controlled by the Multi System software, Class VP 6.12. The separation was performed on an RP-18 chromatographic column (Phenomenex Gemini, 250 x $4.6 \mathrm{~mm}$, with 5 ì m internal particle) provided with guard column (Phenomenex ODS (C18), 4 mm x 3 $\mathrm{mm}$ ), and the detection was done at $450 \mathrm{~nm}$. The current study used mobile phase composed of methanol: ethyl acetate: acetonitrile (80:10:10, v/v/v), HPLC grade (Tedia, Brazil), with $2.0 \mathrm{~mL} \mathrm{~min}^{-1}$ flow and run time of 13 minutes.

The peaks of interest were identified by comparing the retention times of both the standard and the samples and, mainly, by comparing the absorption spectrum of authentic samples and standards analyzed under the same conditions. The $\alpha$-carotene was identified by means of the absorption spectrum. Quantification was performed by external standardization, by means of analytical curves, using regression equations obtained through the concentration correlation versus the standards' peak areas. The results were expressed in $\mu \mathrm{g}(100 \mathrm{~g})^{-1}$ of each plant material, in the wet basis.
The vitamin A value was calculated according to the recommendations from the Institute of Medicine (2001), wherein 1 Retinol Activity Equivalent (RAE) corresponds to $1 \mu \mathrm{g}$ retinol, and it was calculated as follows: $\mu \mathrm{g}$ of $\beta$ carotene $/ 12+\mu \mathrm{g}$ of á-carotene/24, with data expressed in $\mu \mathrm{g}(100 \mathrm{~g})^{-1}$ of each plant part and ripening stage, based on the wet matter.

Total carotenoids were estimated according to the methodology suggested by Higby (1962), and the results were expressed in $\mu \mathrm{g}\left(100 \mathrm{~g}^{-1}\right)$ of pulp and peel.

The current study adopted a completely randomized design in a $15 \times 2$ factorial scheme, being 15 cultivars and two maturing stages (unripe and ripe), with four replications (bunches), and six fruits per sampling unit. Pulp and peel was analyzed as an individual test. Comparisons among fruit parts were made through descriptive statistics.

Data from the variables related to the comparison among cultivars were subjected to variance analysis and the means were grouped according to the Scott-Knott criterion ( $\mathrm{p}<0.01$ ), using the System for Statistical and Genetic Analyses - SAEG (Sistema para Análises Estatísticas e Genéticas) 9.1.

\section{RESULTS AND DISCUSSION}

The $\beta$-cryptoxanthin and lycopene carotenoids were not identified in any fruit part or ripening stage. Lutein, ácarotene and $\beta$-carotene were identified and quantified, fact that was also observed in bananas by other authors (Wall, 2006; Davey et al., 2009; Newilah et al., 2009; Ekesa et al., 2012; Lokesh et al., 2014) (Table 1). The cultivar and the fruit parts, as well as the ripening stage, influenced the evaluated carotenoid concentrations. Figure1 shows the chromatographic typical profile of the carotenoids found in the samples (Terrinha plantain).

Carotenoid concentrations in the unripe pulp varied greatly among cultivars. By analyzing just the overall mean, it was possible to see that there was slight $\beta$-carotene predominance in comparison to the other studied carotenoids, agreeing with Lokesh et al. (2014) and Englberger et al. (2010). As for lutein, five mean groups were formed. 'Ouro' cultivar belonged to the group showing the highest mean, folowed by the group 'Nanica', 'Caipira', 'Mysore' and 'Marmelo', which showed lutein concentration around the half of the presented by 'Ouro'. In addition, lutein concentration exceeded that of ácarotene and $\beta$-carotene in Ouro, Caipira, Prata, Maçã, Pacovan, Prara Graúda and Caju cultivars. Newilah et al. (2009) also observed this trend when they evaluated 19 banana cultivars and plantains in Cameroon. As for ácarotene and $\beta$-carotene, there was variation among cultivars. Eight cultivars showed á-carotene concentration 
higher than that of $\beta$-carotene, in the unripe pulp (Table 1).

There was $36 \%$ increase in lutein concentration in the ripe pulp (mean of all cultivars) in comparison to the unripe pulp. There was increased lutein concentration in the pulp of all tested cultivars due to ripening (from stage 1 to 6), except for Ouro', 'Caru-Roxa' and 'Caju' (Table 1). Similarly, Newilah et al. (2009) observed significant lutein concentration increase in 16 out of 19 banana cultivars evaluated from stage 1 to 7 . The lutein content in Nanicão Caru-Roxa, Caipira, Maçã and Caju cultivars did not differ with the ripening of fruits. In addition, the ripe pulp of all cultivars, except for 'Caru-Roxa', 'Caru-Verde' 'Terrinha' and 'Caju', showed higher lutein concentration than that of the other evaluated carotenoids (Table 1). It corroborates the study done by Wall (2006), Newilah et al. (2009) and Lokesh et al. (2014) who also found higher lutein concentrations in comparison to the other carotenoids found in bananas. However, Davey et al. (2009) and Ekesa et al. (2012) found lower lutein concentration than that of the other carotenoids in ripe banana pulp.

Lutein is a yellow carotenoid and it does not have provitamin A activity (Davey et al., 2009). However, it plays important roles in the human body. Known as macular carotenoid, lutein - along with zeaxanthin - accounts for the yellowish color in the macula, which is a high visual acuity region responsible for the clear view of images (Yeum et al., 1995). Lutein and zeaxanthin are the only carotenoids found in the eye in much higher amount than in any other human tissue (Yeum et al., 1995). In addition, lutein is linked to other benefits, such as decreased risk of developing age-related macular degeneration (AMD), and it also shows beneficial effects on the protection against atherosclerosis, cataract, cancer and other diseases (Koh et al., 2004). Furthermore, lutein presents antioxidant activity, and it protects cells from oxidative damages.

For the $\alpha$-carotene, there was no difference in the content with the ripening of the pulp for any cultivar evaluated, except for 'Terrinha', where the unripe pulp content was higher (Tabela 1). 'Terrinha' stood out with significant á-carotene and $\beta$-carotene concentrations in comparison to the other cultivars in both ripening stages. In addition, it is worth emphasizing that the á-carotene and $\beta$-carotene concentrations in 'Terrinha' unripe pulp were, respectively, approximately 4 and 3 times higher than those found in 'Caru-Roxa' and 'Caru-Verde'. It indicates 'Terrinha' cultivar great potential as source of these pigments. 'Caipira' showed the lowest $\alpha$-carotene and $\beta$ carotene concentrations in both ripening stages although it had been grouped together with other cultivars. Newilah et al. (2009) also found in 'Caipira' pulp in Cameroon very low concentrations of á-carotene (62 and $106 \mu \mathrm{g} 100 \mathrm{~g}^{-1}$, unripe and ripe pulp, respectively) and $\beta$-carotene (13 61 and $100 \mu \mathrm{g} \mathrm{g}^{-1}$, unripe and ripe pulp, respectively), compared with 18 other cultivars.

Similarly to what was seen in the unripe pulp, 'Terrinha' showed wide $\alpha$-carotene predominance in the ripe pulp than the other cultivars, and its concentration was approximately 144 times higher than that found in 'Marme-
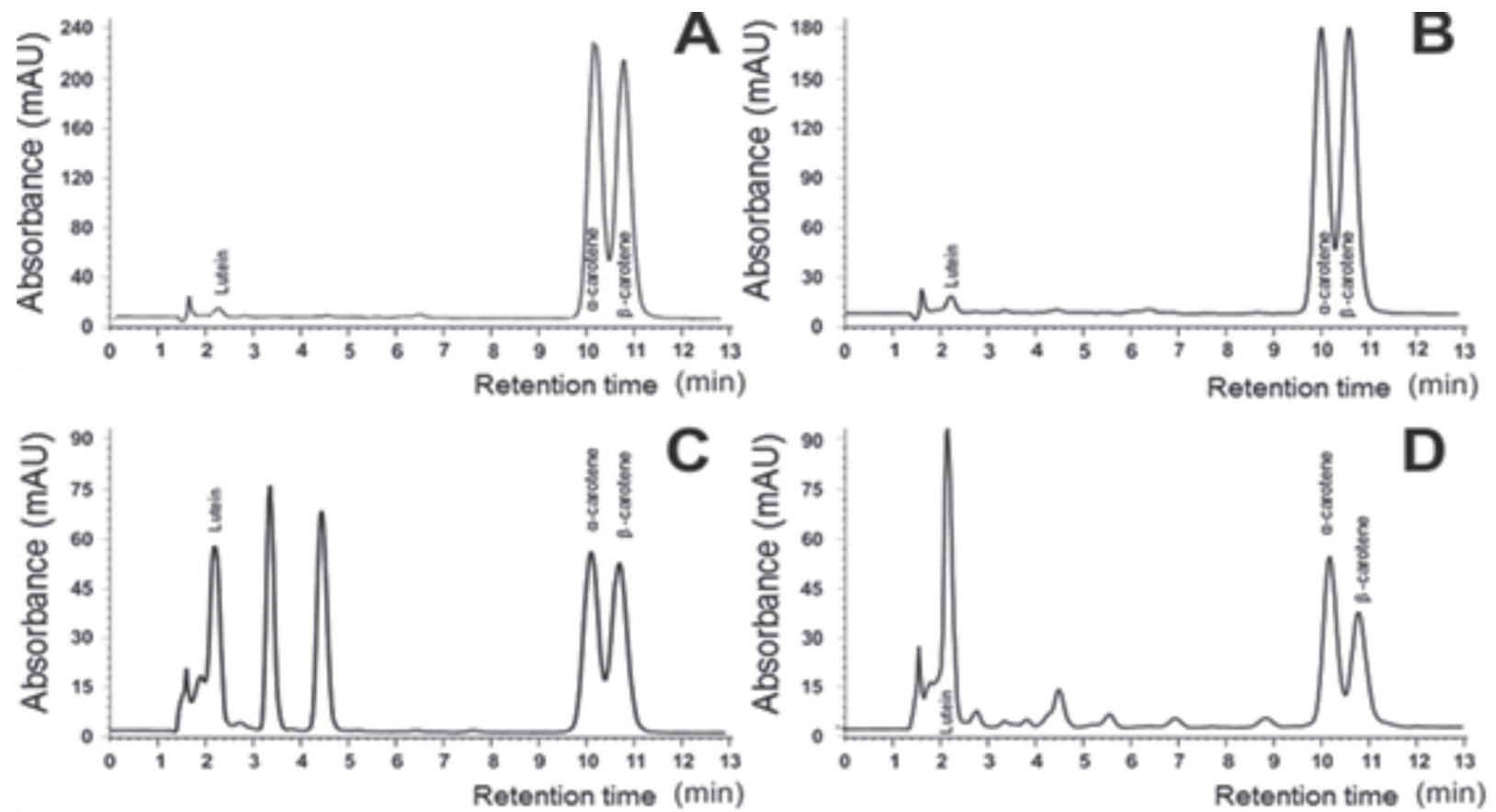

Figure 1: Chromatographic profiles of the lutein, $\alpha$-carotene and $\beta$-carotene carotenoids extracted from 'Terrinha' plantain. (A) unripe pulp (B) ripe pulp (C) unripe peel and (D) ripe peel. The chromatographic conditions are described in Materials and Methods. 
Table 1: Mean carotenoid concentrations and retinol activity equivalents (RAE) based on fresh matter and respective coefficients of variation (CV \%) of unripe and ripe fruit pulp from 15 banana and plantain cultivars grown in Viçosa County, Minas Gerais State

\begin{tabular}{|c|c|c|c|c|c|c|c|c|c|c|}
\hline \multirow{3}{*}{ Cultivars } & \multicolumn{2}{|c|}{ Lutein } & \multicolumn{2}{|c|}{$\alpha$-carotene } & \multicolumn{2}{|c|}{$\beta$-carotene } & \multicolumn{2}{|c|}{ Total carotenoids } & \multicolumn{2}{|c|}{ RAE (in $100 \mathrm{~g}$ ) } \\
\hline & Unripe & Ripe & Unripe & Ripe & Unripe & Ripe & Unripe & Ripe & Unripe & Ripe \\
\hline & ----- & ----- & ------ & $----(\mu \mathrm{g}$ & $\left.\mathbf{0} \mathbf{g}^{-1}\right)--$ & ------ & ------ & ------- & & \\
\hline Ouro & $442.97 \mathrm{aA}$ & $303.15 \mathrm{aB}$ & $137.60 \mathrm{cA}$ & $162.39 \mathrm{cA}$ & $142.03 \mathrm{cB}$ & $209.00 \mathrm{cA}$ & $809.47 \mathrm{bA}$ & $819.34 \mathrm{dA}$ & $17.56 \mathrm{cB}$ & $24.18 \mathrm{cA}$ \\
\hline Nanica & $86.63 \mathrm{eB}$ & $151.74 \mathrm{cA}$ & $104.24 \mathrm{cA}$ & $134.22 \mathrm{dA}$ & $58.35 \mathrm{dA}$ & $103.10 \mathrm{eA}$ & $384.62 \mathrm{cA}$ & $501.47 \mathrm{eA}$ & $9.20 \mathrm{dA}$ & $14.18 \mathrm{dA}$ \\
\hline Nanicão & $122.35 \mathrm{dA}$ & $142.04 \mathrm{cA}$ & $130.61 \mathrm{cA}$ & $106.45 \mathrm{dA}$ & $66.37 \mathrm{dA}$ & $63.97 \mathrm{fA}$ & $447.21 \mathrm{cA}$ & $476.74 \mathrm{eA}$ & $10.97 \mathrm{dA}$ & $9.76 \mathrm{eA}$ \\
\hline Caru-Verde & $132.05 \mathrm{~dB}$ & $219.28 \mathrm{bA}$ & $255.25 \mathrm{bA}$ & $281.79 \mathrm{bA}$ & $290.79 b A$ & $307.18 \mathrm{bA}$ & $895.10 \mathrm{bB}$ & $1.075 .53 \mathrm{cA}$ & $34.86 \mathrm{bA}$ & $37.34 \mathrm{bA}$ \\
\hline Caru-Roxa & $237.86 \mathrm{bA}$ & $229.30 \mathrm{bA}$ & $286.26 \mathrm{bA}$ & $252.19 \mathrm{bA}$ & $362.92 \mathrm{bA}$ & $323.55 \mathrm{bA}$ & $978.80 \mathrm{bB}$ & $1.296 .58 \mathrm{bA}$ & $42.17 \mathrm{bA}$ & $37.47 \mathrm{bA}$ \\
\hline Caipira & $65.71 \mathrm{eA}$ & $101.26 \mathrm{cA}$ & $6.95 \mathrm{dA}$ & $13.89 \mathrm{gA}$ & $3.61 \mathrm{dA}$ & $15.29 \mathrm{fA}$ & $159.66 \mathrm{dA}$ & $183.88 \mathrm{fA}$ & $0.59 \mathrm{dA}$ & $1.85 \mathrm{fA}$ \\
\hline Prata & $132.16 \mathrm{dA}$ & $133.42 \mathrm{cA}$ & $103.78 \mathrm{cA}$ & $57.66 \mathrm{eA}$ & $116.68 \mathrm{cA}$ & $61.36 \mathrm{fB}$ & $462.50 \mathrm{cA}$ & $398.41 \mathrm{eA}$ & $14.04 \mathrm{cA}$ & 7.51eB \\
\hline Prata-Anã & $104.34 \mathrm{~dB}$ & $238.97 \mathrm{bA}$ & $124.59 \mathrm{cA}$ & $75.99 \mathrm{eA}$ & $149.41 \mathrm{cA}$ & $65.93 \mathrm{fB}$ & $493.71 \mathrm{cA}$ & $563.40 \mathrm{eA}$ & $17.64 \mathrm{cA}$ & $8.66 \mathrm{eB}$ \\
\hline Maçã & $164.31 \mathrm{cA}$ & $205.41 \mathrm{bA}$ & $47.63 \mathrm{dA}$ & $8.34 \mathrm{gA}$ & $39.16 \mathrm{dA}$ & $17.26 \mathrm{fA}$ & $279.66 \mathrm{~dB}$ & $496.18 \mathrm{eA}$ & $5.24 \mathrm{dA}$ & $1.78 \mathrm{fA}$ \\
\hline Mysore & $70.38 \mathrm{eB}$ & $184.05 \mathrm{cA}$ & $94.89 \mathrm{cA}$ & $117.32 \mathrm{dA}$ & $174.73 \mathrm{cA}$ & $152.14 \mathrm{dA}$ & $407.09 \mathrm{cB}$ & $604.92 \mathrm{eA}$ & $18.51 \mathrm{cA}$ & $17.56 \mathrm{dA}$ \\
\hline Pacovan & $137.86 \mathrm{~dB}$ & $220.79 b A$ & $104.70 \mathrm{cA}$ & $73.21 \mathrm{eA}$ & $99.32 \mathrm{cA}$ & $51.65 \mathrm{fA}$ & $437.05 \mathrm{cA}$ & $563.29 \mathrm{eA}$ & $12.64 \mathrm{cA}$ & $7.35 \mathrm{eA}$ \\
\hline Terrinha & $99.31 \mathrm{~dB}$ & $192.49 \mathrm{bA}$ & $1.195 .30 \mathrm{aA}$ & $1.073 .03 \mathrm{aB}$ & $1.126 .11 \mathrm{aA}$ & $1.051 .84 \mathrm{aB}$ & 2.553.51aA & $2.583 .23 \mathrm{aA}$ & $143.64 \mathrm{aA}$ & $132.36 \mathrm{aB}$ \\
\hline Marmelo & $33.33 \mathrm{eB}$ & $111.28 \mathrm{cA}$ & $7.28 \mathrm{dA}$ & $7.41 \mathrm{gA}$ & $91.60 \mathrm{cA}$ & $26.76 \mathrm{fB}$ & $167.20 \mathrm{dA}$ & 279.79fA & $7.93 \mathrm{dA}$ & $2.53 \mathrm{fA}$ \\
\hline Prata-Graúda & $112.13 \mathrm{~dB}$ & $280.51 \mathrm{aA}$ & $51.05 \mathrm{dA}$ & $53.04 \mathrm{fA}$ & $42.07 \mathrm{dA}$ & $44.76 \mathrm{fA}$ & $289.62 \mathrm{~dB}$ & $488.96 \mathrm{eA}$ & $5.63 \mathrm{dA}$ & $5.94 \mathrm{eA}$ \\
\hline Caju & $175.91 \mathrm{cA}$ & $169.16 \mathrm{cA}$ & $89.97 \mathrm{cA}$ & $121.82 \mathrm{dA}$ & $71.42 \mathrm{dA}$ & $98.97 \mathrm{eA}$ & $443.93 \mathrm{cA}$ & $429.98 \mathrm{eA}$ & $9.70 \mathrm{dA}$ & $13.32 \mathrm{dA}$ \\
\hline Mean & 141.15 & 192.19 & 182.67 & 169.24 & 188.97 & 172.85 & 613.94 & 717.44 & 23.35 & 20.61 \\
\hline$\overline{\mathrm{CV}(\%)}$ & 19.73 & 16.57 & 26.83 & 13.76 & 24.73 & 16.20 & 16.56 & 12.16 & 24.27 & 13.26 \\
\hline
\end{tabular}

Means followed by the same uppercase within a column and lowercase within a line, for each variable, belong to the same group, by the Scott-Knott criterion at $5 \%$ probability. 
lo', 128 times higher than that found in 'Maçã', and 77 times higher than that found in 'Caipira' (Table 1). In addition, 'Nanica', 'Nanicão', 'Prata-Anã', 'Pacovan', 'Terrinha', 'Prata-Graúda' and 'Caju' showed slightly higher á-carotene concentration than that of $\beta$-carotene. As for the $\beta$-carotene, six mean groups were formed and 'Terrinha' stood out in comparison to the other cultivars once more. In addition, the concentrations of eight cultivars were grouped with the lowest means. Oliveira et al. (2011) found â-carotene concentrations of $366.3 ; 548.6$; and $1557.1 \mu \mathrm{g}(100 \mathrm{~g} \mathrm{MF})^{-1}$ in other fruits, such as 'Paluma' guava, 'Formosa' papaya and 'Tommy Atkins' mango, respectively. They are carotenoid sources for human diet and demonstrate the potential of cultivars such as 'Caru-Roxa' and 'Caru-Verde' - with similar concentrations - and 'Terrinha' - with higher concentration than that of guava and papaya.

As for the ripe pulp, there was 7.3 and $8.5 \%$ reduction in the mean $\alpha$-carotene and $\beta$-carotene concentrations, respectively, due to fruit ripening. There was no difference in the $\beta$-carotene content between ripening stages for most cultivars, except for 'Prata', 'Prata-Anã', 'Terrinha' and 'Marmelo, with higher levels of unripe pulp. For the 'Ouro', the content of the unripe pulp was lower, differing from the content of the ripe pulp (Table 1). The decreased concentrations of these carotenoids during ripening may due to their degradation or to the synthesis of other carotenoids such as lutein (Newilah et al., 2009). On the other hand, Mata et al. (2011) found that ripening led to increased $\beta$-carotene content in 'Ubá' mango; whose content was approximately 3.4 times lower in the unripe fruit.

Similarly to what was seen in the unripe pulp, eight ripe pulp of the analyzed cultivars showed higher mean $\beta$ carotene concentrations than those of $\alpha$-carotene (Table 1), which was also observed by Englberger et al. (2003; 2010), Ekesa et al. (2012) and Lokesh et al. (2014) (cultivars not evaluated in this current study). However, Wall (2006) and Newilah et al. (2009) found higher á-carotene concentrations than those of $\beta$-carotene (cultivars not evaluated in this study). This fact shows the importance of assessing carotenoids occurrence and of quantifying their concentrations in order to provide more accurate nutritional information about each cultivar as well as to encourage the consumption of cultivars with higher nutritional potential.

As for the total carotenoids found in the unripe pulp, four mean groups were formed. The concentrations ranged from 159.66 to $2553.51 \mu \mathrm{g}\left(100 \mathrm{~g} \mathrm{FM}^{-1}\right)$ in 'Caipira' and in 'Terrinha', respectively (Table 1). The scientific literature shows few studies focused on evaluating the different carotenoids in unripe banana pulp.

The mean total carotenoid concentration in the ripe pulp was $17 \%$ higher than that found in the unripe pulp, and the concentrations ranged from 183.88 to $2583.23 \mu \mathrm{g}$ (100 g $\mathrm{FM}^{-1}$ ). There was no difference between ripening stages, except for the cultivars Caru-Roxa, Caru-Verde, Maçã, Mysore and Prata-Graúda, with the highest levels observed in the ripe pulp. (Table 1). 'Terrinha' also showed high carotenoid concentration, which was 14 times higher than that found in 'Caipira', and nine times higher than the concentration found in 'Marmelo', which resulted from high á-carotene and âcarotene concentrations. Amorim et al. (2011) evaluated 62 banana accessions in Brazil - including improved and wild diploids, triploids and tetraploid hybrids - and found total carotenoid concentration ranging from 140 (AAA genotypes) to $1924 \mu \mathrm{g}$ (100 $\left.\mathrm{g} \mathrm{FM}^{-1}\right)$ (AAB genotypes). The lowest concentration was found in 'Caipira'.

The current study found that the total carotenoid concentration in banana ripe pulp varied in a wide range according to the cultivar, as it was also observed by Amorim et al. (2009) who evaluated 42 banana accessions in Brazil and found total carotenoid concentrations ranging from 106 ('Nanica') to $1924 \mu \mathrm{g}\left(100 \mathrm{~g} \mathrm{FM}^{-1}\right)$ ('Saney') in white - and orange-pulp bananas, respectively. On the other hand, Englberger et al. (2010) conducted a study in Micronesia (Oceania) and found concentrations ranging from 130 to $9400 \mu \mathrm{g}(100 \mathrm{~g} \mathrm{FM})^{-1}$. Lokesh et al. (2014) conducted a study in India and found total carotenoids concentrations in bananas ranging from 60 to $2100 \mu \mathrm{g}\left(100 \mathrm{~g} \mathrm{FM}^{-1}\right)$.

The current study found that orange pulp cultivars showed the highest carotenoid concentration both in unripe and in ripe fruits in comparison to white or cream pulp cultivars, similarly to what was verified by other authors (Amorim et al., 2009; Davey et al., 2009; Fungo \& Pillay, 2011) in bananas.

The RAE in the unripe and ripe pulp followed the $\alpha$ carotene and $\beta$-carotene concentration trend, and 'Terrinha' stood out in comparison to the other evaluated cultivars (Table 1). The RAEs were close to those reported by Newilah et al. (2009) in unripe pulp. According to the authors their data ranged from 16.02 to $147.99 \mu \mathrm{mg}(100 \mathrm{~g}$ $\mathrm{FM}^{-1}$ ) in the 'Grande Naine' cultivar and in the 'Mbouroukou' plantain, respectively.

There was a difference between ripening stages only for the cultivars Ouro, Prata, Prata-Anã and Terrinha, similar to that observed in $\beta$-carotene. The mean vitamin $A$ value found in the ripe pulp - expressed in RAE - was $12 \%$ lower than that found in the unripe pulp (Table 1) due to the reduced á-carotene and $\beta$-carotene concentrations and to the change in the relationship between the two carotenoids, which have different weights in the conversion into vitamin A. 'Terrinha' showed high vitamin A value in the ripe pulp, but the concentration was $17 \%$ lower than that found in the unripe pulp. The vitamin A value found in most cultivars in the current study is close 
to that reported by Englberger et al. (2010) who found values ranging from 8 to $435 \mu \mathrm{g}\left(100 \mathrm{~g} \mathrm{FM}^{-1}\right)$. However, Newilah et al. (2009) found values ranging from 9.74 to $78.63 \mu \mathrm{g}\left(100 \mathrm{~g} \mathrm{FM}^{-1}\right)$ and Lokesh et al. (2014) found values ranging from 4 to $114.6 \mu \mathrm{g}\left(100 \mathrm{~g} \mathrm{FM}^{-1}\right)$, therefore, lower than that found in 'Terrinha' in the current study.

Although it is not an eating habit, consuming $100 \mathrm{~g}$ unripe pulp of the 'Terrinha' cultivar analyzed in the current study may provide $20.5 \%$ and $16.0 \%$ Dietary Reference Intake (DRI) of vitamin A to adult men and women, respectively. The same amount of ripe pulp from the same cultivar may provide $18.9 \%$ and $14.7 \%$ RDI of vitamin A to men and women, respectively, based on the RDI of 700 and $900 \mu \mathrm{g} \mathrm{day}^{-1}$ for men and women (19 to 50 years old), respectively (Institute of Medicine, 2001). (Table 1).

Great lutein prevalence was found in comparison to that of the other carotenoids in the unripe and ripe peel. Lutein concentration hardly changed in the ripe peel, only in 'Ouro', 'Terrinha' and 'Caju' did the lutein content differ between maturation stages. 'Ouro' stood out with the highest lutein concentration in the unripe peel, whereas 'Maçã' and 'Pacovan' showed lower concentrations than the other cultivars (Table 2). Delgado-Pelayo et al. (2014) also observed this trend when they evaluated apple peels. According to Pogson et al. (1998), lutein is the most abundant carotenoid found in the photosynthetic tissues of plants. It represents up to $50 \%$ carotenoid concentration in the leaves, and its synthesis is evolutionarily conserved in both terrestrial plants and in green algae. Matos et al. (2009) reported that lutein was the main carotenoid found in coffee leaves, with concentration $16 \%$ higher in leaves subjected to more radiation. These results corroborate those found by Matsubara et al. (2011) who reported that lutein plays an important role in the photoprotection of avocado leaves and that it works in heat dissipation, although its mechanisms are still unknown.

In the peel there was slight reduction in á-carotene and $\beta$-carotene concentrations due to the fruit ripening. This reduction may due to the synthesis of other unidentified and non-quantified carotenoids in the current study, as it can be seen in the unripe peel chromatograms (C) in comparison to those of the ripe peel (D) (Figure 1). The synthesis of other carotenoids due to fruit ripening influenced the total carotenoids concentration, which showed discreet increase from stage 1 to 6 (Table 2). The content of á-carotene varied considerably between cultivars and ripening stages, and in the cultivars Nanicão, Caru-Verde, Caru-roxa, Caipira, Maçã, Prata-Graúda and Caju, there was a significant reduction in the content, differing from the unripe peel. In addition, similarly to what was found in the pulp, the $\beta$-carotene concentration was slightly higher than that of á-carotene, except for 'Ouro', 'Nanicão', 'Terrinha' and 'Caju' cultivars. The $\beta$-carotene concentration was higher than that of $\alpha$-carotene in all genotypes, except for 'Nanicão', 'Maçã' and 'Terrinha' (Table 2).

'Terrinha' stood out with higher á-carotene and $\beta$ carotene concentrations than those found in other cultivars in the peal. In addition, the $\alpha$-carotene concentration in the unripe peel was higher than that found in the unripe pulp, except for 'Caru-Roxa', 'CaruVerde', 'Prata', 'Prata-Anã', 'Pacovan' and 'Terrinha'. The â-carotene concentration in the peel was higher than that found in the pulp, except for 'Caru-Roxa', 'Caru-Verde' and 'Terrinha' (Table 2). 'Terrinha' and 'Ouro' stood out with high $\beta$-carotene concentrations, whereas 'Caipira', 'Prata', 'Prata-Anã', 'Maçã', 'Pacovan', 'Marmelo' and 'Prata-Graúda' cultivars showed the lowest á-carotene and $\beta$-carotene concentrations (Table 2).

As for the total carotenoids in the unripe peel, five groups were formed. 'Ouro' cultivar belonged to the group that showed the highest mean concentrations, with concentrations 3.19 and 3.88 times higher than that found in the unripe and in the ripe pulp of the same cultivar, respectively. The lowest concentrations were found in the peel of 'Marmelo', 'Pacovan' cultivars (Table 2). In relation to the ripening stage, there was a low variation between the contents, with the exception of the cultivars Ouro, Terrinha and Caju, where the contents of the ripe peel were higher and 'Caru-Verde' and Caru-Roxa' with higher contents in the unripe peel (Table 2).

The total carotenoid concentration in the ripe peel was higher than that found in the other fruit parts and ripening stages, except for unripe and ripe pulp for 'Terrinha', which showed higher concentration than that found in the ripe peel. It demonstrates this cultivar potential as carotenoids provider. There was $7.2 \%$ increase in the ripe peel in comparison to the unripe peel, and 'Ouro' cultivar stood out (Table 2). Ajila et al. (2007) conducted a study in India and found total carotenoid concentration 4 to 8 times greater in mango ripe peel than that found in the unripe peel.

The mean vitamin A value in the unripe peel was similar to that found in the unripe pulp. Four groups were formed, and 'Terrinha' stood out again with the highest value in comparison to the other cultivars. However, it is noteworthy that eight of the cultivars were grouped with the lowest means due to the low provitamin A carotenoids concentration presented by these cultivars. Vitamin A value was higher in the unripe peel than in the unripe pulp, except for 'Caru-Roxa', 'Caru-Verde', 'Prata', 'PrataAnã', 'Pacovan' and 'Terrinha'. For the ripening stage, there were higher contents of unripe peel, with the exception of 'Ouro'. Behavior similar to that observed in the contents of $\beta$-carotene in the peel and ripening stages, because of this carotenoid present larger weight in the conversion in vitamin A. 
Table 2: Mean carotenoid concentrations, retinol activity equivalents (RAE) based on fresh matter and the respective coefficients of variation (CV \%) of unripe and ripe peel from15 banana and plantain cultivars grown in Viçosa County, Minas Gerais State

\begin{tabular}{|c|c|c|c|c|c|c|c|c|c|c|}
\hline \multirow{3}{*}{ Cultivars } & \multicolumn{2}{|c|}{ Lutein } & \multicolumn{2}{|c|}{$\alpha$-carotene } & \multicolumn{2}{|c|}{$\beta$-carotene } & \multicolumn{2}{|c|}{ Total carotenoids } & \multicolumn{2}{|c|}{ RAE (in $100 \mathrm{~g}$ ) } \\
\hline & Unripe & Ripe & Unripe & Ripe & Unripe & Ripe & Unripe & Ripe & Unripe & Ripe \\
\hline & \multicolumn{10}{|c|}{ 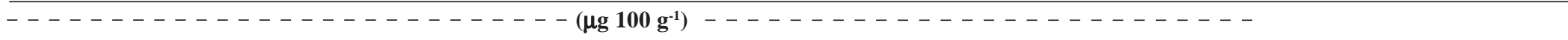 } \\
\hline Ouro & $2310.31 \mathrm{aB}$ & $2587.93 \mathrm{aA}$ & $222.62 \mathrm{cA}$ & $248.77 \mathrm{bA}$ & $209.73 \mathrm{cB}$ & $461.98 \mathrm{aA}$ & $2566.86 \mathrm{aB}$ & $3182.13 \mathrm{aA}$ & $26.75 \mathrm{cB}$ & $48.86 \mathrm{aA}$ \\
\hline Nanica & $1832.04 \mathrm{bA}$ & $1682.72 \mathrm{bA}$ & $178.34 \mathrm{cA}$ & $178.12 \mathrm{cA}$ & $185.89 \mathrm{cA}$ & $190.61 \mathrm{dA}$ & $2007.93 \mathrm{cA}$ & $2012.60 \mathrm{dA}$ & $22.92 \mathrm{dA}$ & $23.30 \mathrm{cA}$ \\
\hline Nanicão & $1561.22 \mathrm{cA}$ & $1579.17 \mathrm{bA}$ & $201.30 \mathrm{cA}$ & $161.66 \mathrm{cB}$ & $195.79 \mathrm{cA}$ & $159.78 \mathrm{dA}$ & $1778.91 \mathrm{dA}$ & $1897.14 \mathrm{eA}$ & $24.70 \mathrm{cA}$ & $20.05 \mathrm{cB}$ \\
\hline Caru-Verde & $1806.19 \mathrm{bA}$ & $1587.27 \mathrm{bA}$ & $183.01 \mathrm{cA}$ & $106.33 \mathrm{~dB}$ & $206.78 \mathrm{cA}$ & $201.35 \mathrm{dA}$ & $2052.37 \mathrm{cA}$ & $1796.38 \mathrm{eB}$ & $24.85 \mathrm{cA}$ & $21.21 \mathrm{cA}$ \\
\hline Caru-Roxa & $1780.92 \mathrm{bA}$ & $1612.19 \mathrm{bA}$ & $216.64 \mathrm{cA}$ & $135.64 \mathrm{~dB}$ & $283.68 \mathrm{bA}$ & $273.55 \mathrm{cA}$ & $2328.36 \mathrm{bA}$ & 1996.32dB & $32.66 \mathrm{bA}$ & $28.45 \mathrm{bA}$ \\
\hline Caipira & $1802.93 \mathrm{bA}$ & $1579.95 \mathrm{bA}$ & $113.37 \mathrm{dA}$ & $51.34 \mathrm{eB}$ & $146.56 \mathrm{dA}$ & $96.81 \mathrm{eB}$ & $1802.69 \mathrm{dA}$ & $1785.88 \mathrm{eA}$ & $16.93 \mathrm{dA}$ & $10.20 \mathrm{~dB}$ \\
\hline Prata & $1801.94 \mathrm{bA}$ & $1653.52 \mathrm{bA}$ & $82.16 \mathrm{eA}$ & $57.27 \mathrm{eA}$ & $118.81 \mathrm{dA}$ & $93.05 \mathrm{eA}$ & $1802.44 \mathrm{dA}$ & $1723.19 \mathrm{eA}$ & $13.32 \mathrm{dA}$ & $10.14 \mathrm{dA}$ \\
\hline Prata-Anã & $1293.88 \mathrm{cA}$ & $1248.62 \mathrm{cA}$ & $80.21 \mathrm{eA}$ & $56.80 \mathrm{eA}$ & $163.93 \mathrm{cA}$ & $88.76 \mathrm{eB}$ & $1355.64 \mathrm{eA}$ & $1438.12 \mathrm{fA}$ & $17.00 \mathrm{dA}$ & $9.76 \mathrm{~dB}$ \\
\hline Maçã & $1282.40 \mathrm{dA}$ & $1317.00 \mathrm{cA}$ & $89.35 \mathrm{eA}$ & $54.34 \mathrm{eB}$ & $118.14 \mathrm{dA}$ & $52.22 \mathrm{eB}$ & $1338.07 \mathrm{eA}$ & $1453.70 f A$ & $13.57 \mathrm{dA}$ & $6.62 \mathrm{~dB}$ \\
\hline Mysore & $1593.81 \mathrm{cA}$ & $1555.30 \mathrm{bA}$ & $138.81 \mathrm{dA}$ & $107.86 \mathrm{dA}$ & $244.69 \mathrm{bA}$ & $212.65 \mathrm{dA}$ & $1740.63 \mathrm{dA}$ & $1898.04 \mathrm{eA}$ & $26.17 \mathrm{cA}$ & $22.22 \mathrm{cA}$ \\
\hline Pacovan & $1195.89 \mathrm{dA}$ & $1004.57 \mathrm{cA}$ & $72.98 \mathrm{eA}$ & $57.31 \mathrm{eA}$ & $117.71 \mathrm{dA}$ & $72.12 \mathrm{eB}$ & $1106.52 \mathrm{fA}$ & $1216.26 \mathrm{fA}$ & $12.85 \mathrm{dA}$ & $8.40 \mathrm{dA}$ \\
\hline Terrinha & $1121.18 \mathrm{cB}$ & $1431.92 \mathrm{bA}$ & $389.95 \mathrm{aA}$ & $398.62 \mathrm{aA}$ & $360.48 \mathrm{aA}$ & $395.10 \mathrm{aA}$ & $1664.55 \mathrm{~dB}$ & $2247.69 \mathrm{cA}$ & $46.28 \mathrm{aA}$ & $49.53 \mathrm{aA}$ \\
\hline Marmelo & $994.88 \mathrm{cA}$ & $995.10 \mathrm{cA}$ & $62.88 \mathrm{eA}$ & $49.50 \mathrm{eA}$ & $185.14 \mathrm{cA}$ & $96.70 \mathrm{eB}$ & $1099.68 \mathrm{fA}$ & $1260.88 \mathrm{fA}$ & $18.04 \mathrm{dA}$ & $10.12 \mathrm{~dB}$ \\
\hline Prata-Graúda & $1273.13 \mathrm{cA}$ & $1400.89 \mathrm{bA}$ & $87.27 \mathrm{eA}$ & $40.56 \mathrm{eB}$ & $170.25 \mathrm{cA}$ & $89.86 \mathrm{eB}$ & $1365.22 \mathrm{eA}$ & $1434.67 f A$ & $17.82 \mathrm{dA}$ & $9.17 \mathrm{~dB}$ \\
\hline Caju & $1948.47 \mathrm{bB}$ & $2529.79 \mathrm{aA}$ & $266.70 \mathrm{bA}$ & $154.48 \mathrm{cB}$ & $246.05 \mathrm{bA}$ & $268.95 \mathrm{cA}$ & $2264.94 \mathrm{bB}$ & $2813.35 \mathrm{bA}$ & $31.61 \mathrm{bA}$ & $28.84 \mathrm{bA}$ \\
\hline Mean & 1573.27 & 1584.39 & 156.17 & 124.57 & 196.90 & 183.56 & 1751.65 & 1877.09 & 22.92 & 20.45 \\
\hline $\mathrm{CV}(\%)$ & 11.65 & 12.33 & 16.19 & 15.36 & 17.59 & 14.04 & 8.42 & 7.19 & 16.48 & 12.03 \\
\hline
\end{tabular}

Means followed by the same uppercase within a column and lowercase within a line, for each variable, belong to the same group, by the Scott-Knott criterion at $5 \%$ probability. 
The vitamin A value in the ripe peel was similar to that found in the ripe pulp, with $11 \%$ decrease in comparison to the unripe peel. 'Ouro' and 'Terrinha' stood out with the highest values, and 'Caipira', 'Prata', 'Prata-Anã', 'Maçã', 'Pacovan', 'Marmelo' and 'Prata-Graúda' cultivars showed the lowest values, since they presented low $\alpha$ carotene and $\beta$-carotene concentrations (Table 2).

The results found in the current study indicated the potential use of certain banana cultivars in promoting health due to the presence of important carotenoid pigments. Some cultivars such as 'Caru-Roxa', Caru-Verde' and 'Ouro' and the 'Terrinha' plantain must be highlighted due to their high carotenoids concentration. In addition, the consumption of fruits from these cultivars should be encouraged. Furthermore, they can be used in breeding programs in order to obtain biofortified cultivars and to help increasing carotenoid intake by people living in regions at risk of vitamin deficiency.

It is worth developing recipes using banana unripe pulp and peel in order to take advantage of the nutritional potential of those parts, which are not usually eaten by the population. However, it is necessary to conduct further studies in order to investigate the anti-nutritional factors and the methods to inactivate them or to reduce them in these fruit parts.

\section{CONCLUSION}

Lutein, á-carotene and $\hat{a}$-carotene are the carotenoids present in the pulp and peel unripe and ripe.

There is an increase in lutein content and reduction in the content of $\alpha$-carotene and $\beta$-carotene with ripening of the pulp.

In the peel, the lutein content hardly change due to fruit maturation, however, there was a reduction in the content of $\alpha$-carotene and $\beta$-carotene.

The mean total concentration of carotenoids increases in the pulp and peel due to fruit ripening.

It is worthwhile to increase or implement the cultivation of the cultivars Terrinha, Caru-Roxa, Caru-Verde and Ouro in regions deficient in vitamin $\mathrm{A}$, due to the higher value of vitamin A.

\section{ACKNOWLEDGEMENTS}

The authors thank the National Counsel of Technological and Scientific Development (CNPq, Brazil) for granting of financial support for research and scholarships.

\section{REFERENCES}

Ajila CM, Bhat SG \& Prasada Rao UJS (2007) Valuable components of raw and ripe peels from two Indian mango varieties. Food Chemistry, 102:1006-1011.
Amorim EP, Cohen KO, Amorim VBO, Paes NS, Sousa HN, Santos-Serejo JA \& Silva SO (2011) Caracterização de acessos de bananeira com base na concentração de compostos funcionais. Ciência Rural, 41:592-598.

Amorim EP, Vilarinhos AD, Cohen KO, Amorim VBO, SantosSerejo JA, Silva SO, Pestana KN, Santos VJ, Paes NS, Monte DC \& Reis RV (2009) Genetic diversity of carotenoid-rich bananas evaluated by Diversity Arrays Technology (DArT). Genetics and Molecular Biology, 32:96-103.

Davey MW, Bergh VD, Markham R, Swnnen R \& Keulemans J (2009) Genetic variability in Musa fruit provitamin A carotenoids, lutein and mineral micronutrient contents. Food Chemistry, 115:806-813.

Delgado-Pelayo R, Gallardo-Querrero L \& Homero-Méndez D (2014) Chlorophyll and carotenoid pigments in the peel and flesh of commercial apple fruit varieties. Food Research International, 65:272-281.

Englberger L, Aalbersberg W, Ravi P, Bonnin E, Mark GC, Fitzgerald MH \& Elymore J (2003) Further analyses on Micronesian banana, taro, breadfruit and other foods for provitamin A carotenoids and minerals. Journal of Food Composition and Analysis, 16:219-236.

Englberger L, Lyons G, Foley W, Daniells J, Aalbersberg B, Dolodolotawake U, Watoto C, Iramu E, Taki B, Wehi F, Warito P \& Taylor M (2010) Carotenoid and riboflavin content of banana cultivars from Makira, Solomon Islands. Journal of Food Composition and Analysis, 23:624-632.

Ekesa B, Poulaert M, Davey MW, Kimiywe J, Van Den Bergh I, Blomm G \& Dhuique-Mayer C (2012) Bioaccessibility of provitamin A carotenoids in bananas (Musa spp.) and derived dishes in African countries. Food Chemistry, 133:14711477 .

Fungo R \& Pillay M (2011) $\alpha$-carotene content of selected banana genotypes from Uganda. African Journal of Biotechnology, 10:5423-5430.

Higby WK (1962) A simplified method for determination of some aspects of the carotenoid distribution in natural and carotene fortified orange juice. Journal of Food Science, 27:42-49.

Koh HH, Murray IJ, Nolan D, Carden D, Frather J \& Beatty S (2004) Plasma and macular responses to lutein supplement in subjects with and without age-related maculopathy: a pilot study. Experimental Eye Research, 79:21-27.

Kurahashi N, Inoue M, Iwasaki M, Tanaka Y, Mizokami M \& Tsugane S (2009) Vegetable, fruit and antioxidant nutrient consumption and subsequent risk of hepatocellular carcinoma: a prospective cohort study Japan. British Journal of Cancer, 100:181-184.

Lokesh VL, Divya P, Puthusseri B, Manhunatha G \& Neelwarne B (2014) Profiles of carotenoids during post-climacteric ripening of some important cultivars of banana and development of a dry product from a high carotenoid yielding variety. LWT Food Science and Technology, 55:59-66.

Mata GMSC, Oliveira DS, Della Lucia CM, Campos FM, Queiroz JH \& Pinheiro-Sant'Ana HM (2011) Teores de â-caroteno e vitamina C durante o amadurecimento da manga 'Ubá' (Mangifera indica L. var. Ubá). Revista do Instituto Adolfo Lutz, 70:225-229.

Matos FS, Wolfgramm R, Gonçalves FV, Cavatte PC, Ventrella MC \& Damatta FM (2009) Phenotypic plasticity in response to light in the coffee tree. Environmental and Experimental Botany, 67:421-427.

Rev. Ceres, Viçosa, v. 65, n.3, p. 217-226, mai/jun, 2018 
Matsubara S, Chen YC, Caliandro R \& Govindjee Clegg RM (2011) Photosystem II fluorescence lifetime imaging in avocado leaves Contributions of the lutein-epoxide and violaxanthin cycles to fluorescence quenching. Journal of Photochemistry and Photobiology B: Biology, 104:271-284.

Newilah GN, Dhuique-Mayer C, Rojas-Gonzalez J, Tomekpe K, Fokou E \& Etoa FX (2009) Carotenoid contents during ripening of banana hybrids and cultivars grown in Cameroon. Fruits, 64:197-206.

Oliveira DS, Aquino PP, Ribeiro SMR, Proença RPC \& PinheiroSant'Ana HM (2011) Vitamina C, carotenoides, fenólicos totais e atividade antioxidante de goiaba, manga e mamão procedentes da Ceasa do Estado de Minas Gerais. Acta Scientiarum. Health Sciences, 33:89-98.

Pinheiro-Sant'Ana HM, Stringheta PC, Brandão SCC \& Azeredo RM (1998) Carotenoid retention and vitamin A value in carrot (Daucus carota L.) prepared by food service. Food Chemistry, 61:145-151.

Pogson BJ, Niyogi KK, Björkman O \& Dellapenna D (1998) Altered xanthophyll compositions adversely affect chlorophyll accumulation and nonphotochemical quenching in Arabidopsis mutants. Proceedings of the National Academy of Sciences, 95:13324-13329.
Rodriguez-Amaya DB (2001) A guide to carotenoid analysis in foods. Washington, International Life Sciences Institute Press. $71 \mathrm{p}$.

Rodriguez-Amaya DB \& Kimura M (2004) Harvest plus handbook for carotenoid analysis. Washington, International Food Policy Research Institute and International Center for Tropical Agriculture (CIAT). 58p.

Institute of Medicine (2001) Dietary Reference Intakes for vitamin A, vitamin K, arsenic, boron, cromium, copper, iodine, iron, manganese, molybdenium, nickel, silicon, vanadium and zinc. Washington, National Academy Press. 772p.

Wall MM (2006) Ascorbic acid, vitamin A, and mineral composition of banana (Musa sp.) and papaya (Carica papaya) cultivars grown in Hawaii. Journal of Food Composition and Analysis, 19:434-445

Yeum KJ, Taylor A, Tang G \& Russell RM (1995) Measurement of Carotenoids, Retinoids, and tocopherols in human lenses. Investigative Ophthalmology \& Visual Science, 36:2756-2761. 